\title{
Islam, culture and authoritative voices in the UK and the US
}

\author{
Patterns of orientation and autonomy among Muslims in art
}

\author{
Yolanda van Tilborgh $(1)$
}

Published online: 12 April 2018

(C) The Author(s) 2018.

\begin{abstract}
British and North American Muslim performing artists have the opportunity to translate Islamic knowledge in relation to art in various ways and in circumstances in which religion may be no longer obviously anchored in culture. At the same time, a reversed autonomisation in the field of Muslim artists seems at stake. If the main drive of the agents in the field is to improve social positions, according to Bourdieu, how can the level of autonomy of the field of Muslim performing artists in the UK and the US be understood? Taking the Bourdieusian concepts of field, habitus, capital into account, this paper intends to investigate in which ways the fields of art and religion intersect and how the orientations to art, culture and Islam are distributed among Muslim artists in the Muslim-minority contexts of the West.

The present chapter will explore the kind of authoritative voices and the significance of relative autonomy in the field of Muslim artists in hip-hop, stand-up comedy, poetry, theatre and contemporary art considered from empirical data through in-depth interviews, content analysis of secondary sources and structural analysis of cultural events in the UK and the US. The disparate ideological orientations are influenced by views to restrict or, in contrast, reinforce the significance of art and culture and imply distinct struggles for social and artistic autonomy. Ranging from strict to secular perspectives, the encountered cultural views are assessed by their relatively weak and strong ties with the field of religion and the field of art. Reflecting gender, race and ethnic background as categories of difference, the scheme of cultural orientations might be transferable to other settings in which culture, religion and ideology are involved.
\end{abstract}

Y. van Tilborgh ( $\triangle)$

Oxford Opleidingen, Utrecht, The Netherlands

E-Mail: tilborgh@xs4all.nl 
Keywords Religious Authority · Muslim Performing Artists · Field of Art · Culture and Race in Islam · Islamic knowledge · North American Sufism · British Salafism

\section{Islam, Kultur und autoritative Stimmen im Vereinigten Königreich und den USA}

Orientierungs- und Autonomiemuster unter Muslimen in der Kunst

Zusammenfassung Muslimischen darstellenden Künstlern aus Großbritannien und Nordamerika bietet sich die Gelegenheit islamisches Wissen im Verhältnis zur Kunst auf verschiedenste Weise und unter verschiedenen Umständen umzusetzen. Hierbei kann es passieren, dass Religion nicht mehr offensichtlich in Kultur verankert ist. Gleichzeitig scheint auf dem Gebiet der muslimischen Kunst eine umgekehrte Autonomisierung im Gange zu sein. Wenn die Verbesserung der sozialen Position, so Bourdieu, der Hauptanreiz der Handelnden auf diesem Gebiet ist, wie kann das Level an Autonomie im Bereich der muslimischen darstellenden Künstler im Vereinigten Königreich und den USA verstanden werden? Dieser Artikel untersucht, unter Berücksichtigung der Bourdieu'schen Konzepte von Bereich, Habitus und Kapital, wie sich Kunst und Religion überschneiden und wie die Einstellungen zu Kunst, Kultur und Islam unter muslimischen Künstlern im Minderheiten-Kontext des Westens verteilt sind.

Das vorliegende Kapitel erforscht die Arten autoritativer Stimmen und die Bedeutung relativer Autonomie der muslimischen Künstler in den Bereichen Hip-Hop, Stand-up-Comedy, Poesie, Theater und zeitgenössischer Kunst. Einbezogen werden empirische Daten aus Tiefeninterviews, Inhaltsanalysen von Sekundärquellen und strukturellen Analysen kultureller Veranstaltungen im Vereinigten Königreich und den USA. Die verschiedenartigen ideologischen Einstellungen werden beeinflusst durch Sichtweisen, die die Bedeutung der Kunst und Kultur entweder einschränken oder aber verstärken und bedeuten deutliche Anstrengungen um soziale und künstlerische Autonomie. Die gefundenen kulturellen Sichtweisen, deren Perspektiven von streng-religiös bis säkular reichen, werden auf Grundlage ihrer relativ schwachen oder starken Verbindungen zu den Bereichen Religion und Kunst bewertet. Das hier angewandte Schema kultureller Einstellung könnte durch die Berücksichtigung von Geschlecht, Rasse und ethnischem Hintergrund als unterscheidende Kategorien auch auf andere Situationen angewandt werden, die Kultur, Religion und Ideologie beinhalten.

Schlüsselwörter Religiöse Autorität · Muslimische darstellende Künstler · Bereich der Kunst · Kultur und Rasse im Islam · Islamisches Wissensschatz •

Nordamerikanischer Sufismus · Britischer Salafismus 


\section{Introduction: Autonomisation in the field of art}

The theme of the (in)compatibility of (popular) art and music with practised religion reflects the struggle for cultural capital and legitimate knowledge among religious authorities and people of faith. In particular, this is the case concerning Muslims and Islam. Similar to discussions in Christianity in Western Europe about whether art can serve as praise of God and motivate ethical action or, on the contrary, stirs immodest behaviour (Brown 2000, p. 55), there is an ongoing discourse among many Muslims on the (im)permissibility of (popular) art in Islam even in Western democracies (see also Aidi 2014, pp. 44-70; Mandaville 2009; Abdul-Khabeer 2007; Van Tilborgh 2016b). Disputes about dance are found in hadiths during the lives of the Prophet Muhammad and his Companions (Abd-Allah 2004), those about musical instruments among theologians from the time after the Prophet (Shiloah 1995, pp. 31-35) and those about hip-hop music, singing Muslim women and stage behaviour can be found in current times, such as at the debate 'Music-Singing or Sinning?', which I attended in the East London Mosque in 2009. In these discussions, authoritative voices play a role. Authority can be understood as a relation to religious specialists (e.g. imams, teachers and scholars) and movements that mediate interpretations of scripture or that justify and empower certain beliefs and practices. ' 'Authoritative voices' is a slightly broader conception of this notion.

Since many Muslims still perceive the Middle East to be the centre of Islamic knowledge, views on the (im)permissibility of music and entertainment in Islam among Arab authoritative voices influence debates globally. Based on the categorisation by Otterbeck, the 'hard-line' view holds that music should be largely forbidden because it arouses the kind of passion that is not religiously centred and destroys public morality (Otterbeck 2004, pp. 15-16, 2008, 2016). The exponents of this counter power stance regard (popular) music as a part of North American cultural imperialism, which acts as a serious rival to Islam. In contrast, the 'liberal' view tends to minimise censorship in the domain of art while upholding the understanding that competing worldviews are good for Islam. In between, scholars and teachers of the 'moderate' view judge productions of popular art as conditionally permissible. That is, when art springs from halal intentions and is morally and socially beneficial to Islam and society at large.

In the history of Western Europe, there is a long tradition of combining art and craftsmanship with civilising goals and religious morals. Throughout Christian history, theologians have attempted to set forth universal guidelines for art, such as the desiderata of dignity and restraint (Brown 2000, p. 55). Since the Middle Ages, specific Christian orders issued commissions among craftsmen to artistically express warnings against hell and damnation as well as recommendations to good conduct and communal spirit (Kempers 1992, pp. 21-77). From the Renaissance on, however, craftsmen became increasingly less dependent on church or state. $\mathrm{Mu}-$ sicians, visual artists and theatre performers received assignments of a growing middle class (De Swaan 1991). Through the reduction of moral censure, religious proselytising programmes and the political use of art for propaganda, this process

\footnotetext{
1 Based on the definition of authority in Religious Authority and Authority Intertwined (Jensen 2006).
} 
of autonomisation meant the growing importance of aesthetic standards while individual expressions became dominant (Bourdieu 2009, pp. 112-4; Gombrich 1982, p. 398; Oosterbaan Martinius 2005, p. 209). Over the course of time, regarding the political and economic fields in Western Europe, professional artists have formed a relatively autonomous field of cultural production that imposes its own principles of legitimacy, meanwhile rejecting external demands from one single source (Bourdieu 2009, pp. 21, 52-54; Oosterbaan Martinius 2005). This autonomy and the related Western ideal of autonomous art are even more crucial with regard to the field of religion.

Yet, questions have arisen on the autonomy of the field of contemporary West European and North American Muslim performing artists. From the 1990s onward, public discussion among Muslims focusing on contested expressions of (popular) art by Muslims has grown. At the debate 'Music-Singing or Sinning?', the dispute over the justification of controlling cultural habits versus loosening cultural restrictions became heated. The art and Islam discourse is reinforced by the popularity of the tenet that tends to severely restrict forms of art and music: Salafi Islam. This phenomenon makes it crucial to put the assumed independency of the field of Muslim performing artists in the West into perspective.

\section{Theoretical framework: The fields of art and religion \& accommodationism}

Because the coherent concepts of field, capital and practices of Pierre Bourdieu are meant to explain struggles in culture, they will guide, among others, the study of the field of Muslim performing artists in the UK and the US. Just like those in the field of art, agents and institutions in the field of religion, compete for the control of legitimate forms of capital (Bourdieu 1971; Rey 2004). Cultural and symbolic capital apply to social status in the religious community, to knowledge concerning religious doctrines and traditions, and to recognised authority with regard to moral approval and the insurance of salvation (Rey 2004), which are all the more important in case the fields of art and religion intersect. At stake is the legitimation of the social order, the sanction of those holding power and the definition of meaning that religion brings to people's lives. In terms of defining power, agents with relevant capital can become dominant with their specific interpretation of legitimate art (Bourdieu 1996, pp. 223-7, 2009). Although fields are embedded in social space and influenced by adjacent and dominant fields and their habitus, they are relatively autonomous due to their unique underlying rules, purposes and varying structures (Bourdieu 1966, 2009; Bourdieu and Wacquant 1992, p. 97).

Connected to habitus, the set of cultural dispositions, and capital, Olivier Roy's concept of accommodationism pertaining to religion is used in the present paper to discuss the different attitudes towards practising Islam in culture and vice versa. 


\subsection{Accommodationism: Embedded religion and Islamic knowledge}

More specifically, the field of Muslim performing artists can be understood from the conceptions of embedded religion, universal religion and religious individualisation with regard to authority in Islam. Olivier Roy argues that, as a result of globalisation and migration, religions have become standardised, generating forms of religiosity that transcend space, ethnicity and culture (Roy 2004, 2010; Hamid 2016). The quest for purity has led to a focus on the fundamentals by stripping religious expressions of particular local and ethnic properties (Roy 2010). One of these expressions is Salafi Islam, which can be interpreted as textual literalism driven by a modernist reform movement that emphasises strict behavioural standards of the early period in Islam (Esposito 1998, p. 823; Lapidus 2002, pp. 315-6). Its aim is to revitalize the Islamic society of today.

When stating that religious beliefs are no longer embedded in contemporary culture, Roy refers to symbolic systems as well as the ethnic, local and national understanding of culture (2010, p. 26). Religious orientations that are anchored in the philosophy and literature of cultures display the 'accommodationist attitude' by adapting beliefs to the cultural environment and, reversed, by allowing that the norms and traditions of one's society shape how religion is expressed through art, music and language.

Although globalised Islam has lost its dependence on localised social authority, i.e. imams and parents, new types of informal popular religious authority have been created in the context of Westernisation (Roy 2004; Van Bruinessen and Allievi 2011; Hamid 2016). Aligned with greater access to religious knowledge, the process of individualisation has lead Muslims to compose personal forms of Islamic wisdom (Van Bruinessen and Allievi 2011, p. 2; Sunier 2011, p. 149). At the same time, a most noticeable relative stability of Islamic dogmas is found (Mandaville 2007; Van Bruinessen and Allievi 2011, p. 19; Wiktorowicz 2006). Concerning Islamic authoritative directions, Volpi and Turner distinguish the 'traditionalist perspective', which employs aspects of the tradition conducive to keeping in tune with the expectations of ordinary believers; the 'reformist perspective', which is eager to revise certain institutions that justify traditional forms of Islamic authority but not all; and the 'radical perspective', which questions Islamic authority and challenges the very foundations of the corpus of religious knowledge (2007). The individualisation of religious beliefs has, however, not resulted in questioning complete religious dogmas but differs strikingly per religious theme (Göle 2003; Pedziwiatr 2011). It is also arguable whether individual choice in the privatised religious practice may disentangle the presumed ties between the ethno-national identity, cultural tradition and religious strand (Yukleyen 2010; Cesari 2004, pp. 43-64; Volpi and Turner 2007, p. 4).

Translating the perspectives discussed above, British and North American Muslim performing artists have the opportunities to translate Islamic knowledge in relation to art in various ways and in circumstances in which religion may be no longer obviously anchored in culture. At the same time, a reversed autonomisation in the field of Muslim artist seems at stake. If the main drive of the agents in the field is to improve social positions, how can the level of autonomy of the field of Muslim 
performing artists in the UK and the US be understood? Taking the Bourdieusian concepts of field, habitus, capital into account, this paper intends to investigate in which ways the fields of art and religion intersect and how the orientations to art, culture and Islam are distributed among Muslim artists in the Muslim-minority contexts of the West. It will discuss the kind of interaction with the field of Islam and the significance of relative autonomy. ${ }^{2}$

\section{Context: Muslims in the UK and the US}

From the 1960s on, the UK recruited many uneducated labourers for their growing industries - in contrast to the US, which attracted mainly educated immigrants from the Middle East and South Asia. For most first-generation Muslims, Islam was an aspect of their ethnic identity, and faith adherence had more to do with participating in communal life (Hamid 2016, p. 8). The educated offspring came to perceive their parents' religiosity as 'folk Islam' ruled by culturally tainted, ethnic habits (Jacobson 1998, pp. 143-51; Mandaville 2009; Roy 2004, p. 138). They needed a new approach to get ahead. Generally, there is an ongoing discursive attempt to separate core Islamic values from problematic ethnic practices (Van Tilborgh 2009; Hamid 2016, p. 101).

The new approaches to distinguish Islam from culture also targeted Sufism, the mystical dimension of Islam. Although Sufism, which pursues the interior path of spiritual purification and closeness to God, is based on accepted ideas about devotion among Muslims in general (Bowen 2012, p. 119; Hamid 2016), it also engenders disapproval. Represented by the Barelwi school, the kind of Sufi Islam popular among South Asian Muslims emphasises personal piety, but leaves, along with stringently following just one of the Sunni (Hanafi, Maliki, Shafi'i, Hanbali) schools of Islamic jurisprudence, little room for independent reasoning: ijtihad (Hamid 2008, 2016, p. 10; Lapidus 1997). Particularly, the general use of music and dance in tasawwuf-Sufi-devotional practices has caused distrust among many Muslims (see also Van Bruinessen and Howell 2007). ${ }^{3}$

The British popularisation of Salafism, which strives to purify Islam from what are considered inauthentic elements, can be understood as a way of many young Asian Muslims as well as Black and White convert Muslims to reflect on dominant cultural habits and dispose Islam of misrepresentations. Salafism has provided a faction of disgruntled, humiliated young people with the possibility to identify with a strong kind of community membership, as a special sect with access to 'the Truth' (Hamid 2009, p. 390; Meijer 2009, p. 13). Disregarding the complexities of theology and the subtleties of Sufism to detract evidence from religious sources, when consciousness was raised about the worldwide unjust position of Muslims, the kind of religious

\footnotetext{
${ }^{2}$ I would like to acknowledge the peer reviewers and editor of $Z R G P$ for their valuable comments.

3 Bagasra, Anisah (2014) A short history of Sufism and Sufi communities in America. Retrieved from: israinternational.com/latest-news/110-a-short-history-of-sufism-and-sufi-communities-in-america.htmlAnd: Godlas, Alan (2003) Sufism, the West, and Modernity. Retrieved from: islam.uga.edu/ sufismwest.html (accessed April 8, 2017).
} 
identities formed in these networks transcended the bonds based on nationality, ethnicity and race (Hamid 2009; Volpi and Turner 2007).

Although an important number of British Muslims with immigrant backgrounds have chosen to seek a strict kind of Islam, in contrast, a major faction became largely secular in the UK (Mandaville 2007). In the US, previous Muslim newcomers had tried to gain acceptance within mainstream national culture by distancing themselves from Islamic practices but were caught up by successful professional immigrants who pursued to develop an Islamic identity that countered the assimilated migrant identity (Khan 2003). Mandaville observed a comprehensive, inclusive Islam among those who regarded Islam compatible with common values found in other moral systems (2007, p. 294).

The impressive success of the Salafi movement in the West, brought about in literalist, political and reformist currents that contested each other, prompted a reaction of leaders following the Sunni schools of Islamic jurisprudence (Hamid 2008, 2009, 2016). Recognising tassawuf_Sufism — as being an essential part of original Islam, the success of the 'Sufi fightback' was brought on by their appeal to the earlier Islamic tradition and orthodoxy through ideas of great methodological and rhetorical value. Initially popularised by American scholar and convert Muslim Hamza Yusuf, born Mark Hanson, this renewed classical Islam has countered the literalist Salafi trends and appropriated some of the authority of Salafi teachers by explaining an alternative scholarly and activist form of Sufism (Hamid 2008, 2009, 2016). Sufism's popularity can also be understood as being a spiritual response to secularisation while avoiding the activist excesses of the radical Islamic movements (Geaves 2010). In the transnational Anglo-American 'Traditional Islam' network, ${ }^{4}$ several like-minded convert Muslim scholars have popularised Hamza Yusuf's message by attempting to deconstruct Salafis' claims to textual orthodoxy and accommodate sophisticated understandings of Islamic civilisation (Hamid 2009, 2016). Apparently, these styles have increased Sufism's symbolic capital.

Also structuring the field, a large number of Muslims experience an in-group power imbalance between indigenous Blackamerican Muslims, who developed Islam from the institutions of Black Religion such as the Nation of Islam, and immigrant Muslims. While the first consider that original Islam was brought to the US by their enslaved ancestors, the latter brought the kind of Islam from the Middle East and South Asia after the inclusive Immigration and Nationality Act of 1965 and have occupied notable positions in Muslim institutions in the West since then (AbdulKhabeer 2007; Jackson 2005, pp. 3-21; McCloud 2006, pp. 123-37). Generating a picture of dominant and dominated religiosity, the definitions of Islam expressed by indigenous (Blackamerican $)^{5}$ Muslims are considered to be less easily accepted

\footnotetext{
${ }^{4}$ Several institutions play and have played an important role in this network. In the UK, British Radical Middle Way (RMW) promoted a moderate understanding of Islam by means of lectures combined with performances of popular culture, organised, among others, by Abdul-Rehman Malik. In the US, the InnerCity Muslim Action Network (IMAN) delivers social services in combination with a cultivation of the arts in urban communities, initially organised by performing artist Asad Jafri.

5 Sherman Jackson identifies 'Blackamericans' instead of 'African Americans' to stress that the force of American history has 'transformed these erstwhile Africans into a new [Western] people' (2005, pp. 17-18).
} 
socially than those of successful immigrant professionals (McCloud 2003; Jackson 2009).

Made clear by the previous context, to understand the distribution of orientations among Muslim artists in the UK and the US on the meta-level, it will be necessary to look beyond the indicators of class and education to race and ethnicity as well.

\section{Research methodology}

In the present paper, the empirical findings, based on an ethnographic study of Muslim performing artists in the UK and the US between 2009 and 2012, are discussed by linking the concept of habitus with the concept of intersectionality through identifying the significance of ethnic and religious background. Intersectionality studies the modalities of social formations regarding boundaries and hierarchies in social life (Anthias 2013). At the time of research, the artists were engaged in cultural production in Anglophone hip-hop and alternative music, spoken word and poetry, storytelling, theatre and acting, stand-up comedy, film performance and contemporary art on stage. ${ }^{6}$ They are mainly self-acclaimed Muslims who have brought Islam, or experiences related to being Muslim, to the fore in at least one of their artistic performances. To study how Muslim artists synthesise their artistic identity with their religious conceptions, British and North American artists are chosen for reasons of comparability in terms of language and background while at the same time, at first sight, they display contrasting religious leanings. Besides drawing on secondary literature from academic sources as well as traditional and digital media, semi-structured in-depth interviews on art, culture and Islam were conducted with sixty-five Muslim performing artists and eight stakeholders, including art managers and Islamic teachers in the UK and the US. ${ }^{7}$ In addition, twenty-three similar participants in art (artists and stakeholders) were studied through short interviews and/or secondary sources. ${ }^{8}$ The eventual focus group of seventy artists includes religiously strictly practising, moderately practising and less strictly practising Muslims; for reasons of comparison, there is also a small category of artists with just a Muslim background. ${ }^{9}$ Specifically, I attended seventy religio-artistic events, including biographical artistic performances, to collect additional ethnographic data on the orientations of Muslim artists through participant observations. ${ }^{10}$

\footnotetext{
6 The broader study has left out artists of productions in other (Urdu, Punjabi) languages.

7 For meeting respondents, particularly the method of online and offline snowball sampling is used.

8 Information about the artists derives predominantly from (a) in-depth interviews, but also from combinations of (a), (b) short interviews, (c) content analysis of secondary sources and (d) content analysis of (biographical) performances and Q\&A sessions.

9 These three artists do not self-identify as Muslim, but tend to stand for Muslims after 9/11 or are affiliated with (secularised) Sufism.

10 Using MAXQDA software for mixed qualitative and quantitative methods of analysing, the interviews are deconstructed along sensitising sociological concepts deriving from process sociological theories, symbolic interactionist theories and self-developed categories.
} 
The artists in the broader study include (a) 'born Muslims' and (b) 'convert Muslims', who have chosen the religion of Islam later in life. Also comprising 'born-again Muslims', ${ }^{11}$ the first are predominantly born in South Asian and Middle Eastern Muslim, immigrant families. The latter artists range from indigenous Muslims including African Americans and (White) Natives to immigrants from the Caribbean and African countries, such as Jamaica and Mozambique. Although some Black artists are 'born Muslims' from Nigerian and Somali Muslim families, along racial lines more Black artists are found among convert Muslim artists in the present study.

\section{Empirical findings: Categories in cultural orientations}

Based on systematic analysis of (predominantly in-depth) interviews with Muslim performing artists in the UK and the US, analysis of secondary sources regarding their ideas and productions and participant observation of numerous Muslim cultural events, the religio-artistic views of British and North American Muslim performing artists can be distinguished by five partly overlapping ideological standpoints related to habitus and cultural tastes. These views range between the strict view, the civilisational view, the secular view and the artistic view, and these are more or less centred by the conditional view. They differentiate from each other by their varying relationships with the field of religion and the field of art. The artists can have relatively weak or relatively strong ties to these crucial fields, based on the level on which they take notice of relevant religious advice and aim to connect with the institutions of cultural heritage and those representing contemporary art.

\subsection{The conditional view}

The view that 'art and music are conditionally permissible' is found in the centre of the field of Muslim performing artists in the UK and the US (Fig. 1). In the conditional view, art takes care of guidelines acquired from religion. Resembling the moderate kind of stance to art and music in other major religions, it legitimates cultural productions with content that is considered appropriate, i.e. deriving from decent intentions of the maker and performed in proper circumstances. This conditional view advocates social and elevating cultural intentions of a non-sexual nature that endeavours to be beneficial to human beings generally. While Bourdieu emphasises the opposition between the 'pure' artistic subfield and other subfields, in the present study, views in the centre of the field play and important, and partly connecting, role. Tacit agreements that construct a specific art world, as conceptualised by Howard Becker (1982), also come to the fore.

In the field of British and North American Muslim artists, 'consciousness' by 'raising awareness' turns out to be a central notion, revealed in socially conscious hip-hop, stand-up comedy and poetry. With this particular taste towards high cul-

11 After revaluing the principles of Islam later in life, they changed their ways of expressing religiosity and practising their faith often with increased conviction. 


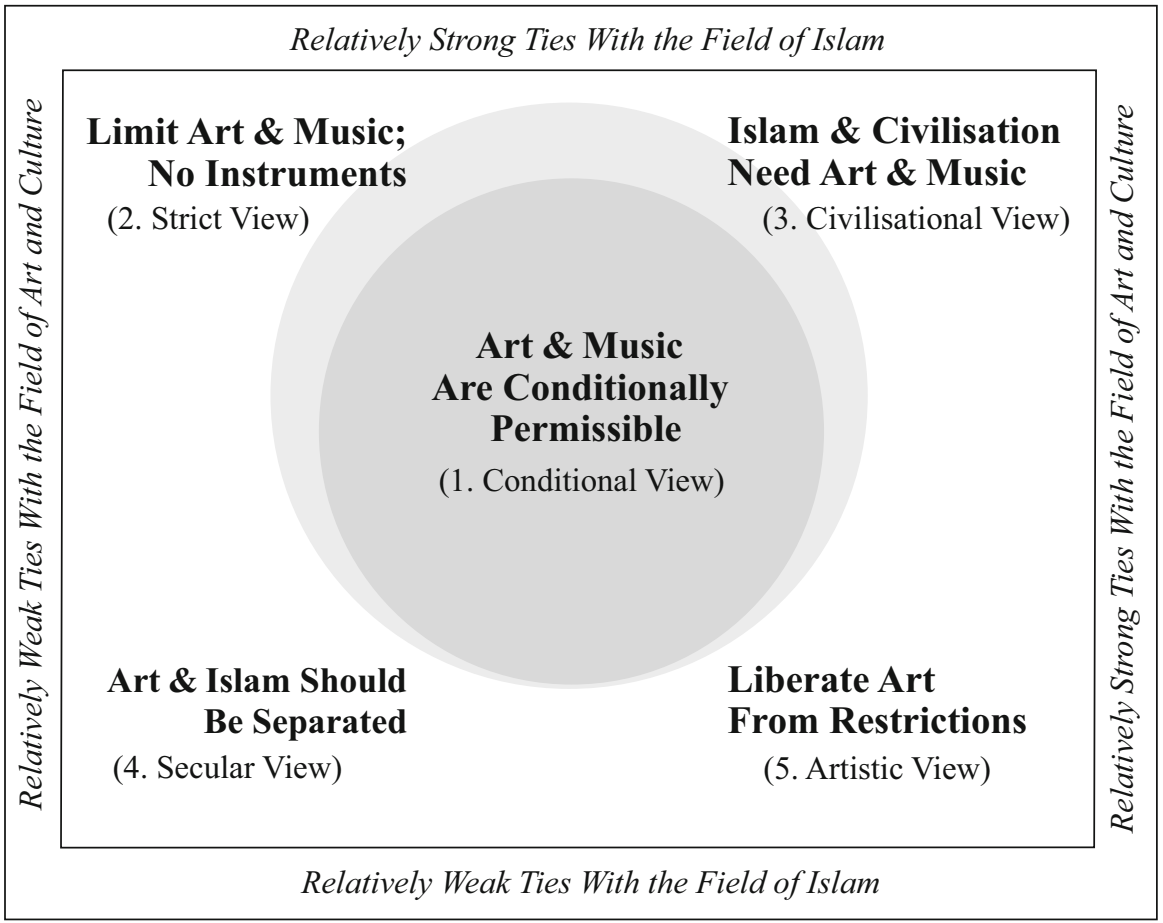

Fig. 1 Pattern of Cultural Views to Art and Islam. The distribution of cultural views in the (sub)field of Muslim performing artists in the UK and the US, related to the field of art and culture and the field of religion, i.e. the (sub)field of Islam

ture, Muslim artists distinguish themselves and their practices from other performing artists in general. The notion of consciousness is inspired by the style of socially conscious hip-hop in the US, meaning that radical change derives through selfknowledge and social awareness. This idea developed not among Muslim artists especially, but among artists with a focus on Black self-determination and issues of the inner-city youth, who integrated religious topics in the course of time (Miyakawa 2005; Rose 2008, pp. 241-7). ${ }^{12}$ Many Muslim rap artists externalised these preferences for consciousness to counter the considered commercial and sexist style of gangsta rap. Regarding mainstream entertainment, several Muslims have taken a similar position in the long tradition of socially conscious comedy that leaves out sexist and racist topics. This tendency reflects that art and music have become serious means to react to public discourse and upgrade the Muslim image in the West (see also Boubekeur 2007; Herding 2013). It also shows an important two-way mode of distinction by which the culturally restrictive and restricted Muslims from the immigrant communities are persuaded into the world of art and imagination. This trend started even before 2001, with the nights of poetry, rap and spirituality of Califor-

${ }_{12}$ Conscious Hip Hop. Retrieved at: rateyourmusic.com/genre/Conscious\%20Hip\%20Hop/2 (accessed April 8, 2017). 
nian collective Calligraphy of Thought by, among others, American British Pakistani Hana Siddiqi, and her later initiative Muslims Engaged in Creating Consciousness in America (MECCA). For the same purpose of inspiring Muslim audiences, Indian American Azhar Usman and African American Preacher Moss, who were successful comedians in the American mainstream, formed the group Allah Made Me Funny to play in (religious) centres with gender segregated seating. Artistic institutions have come to life, from the Khayaal Theatre Company of Luqman Ali-through the dramatic interpretation of classic Muslim world literature connected with Muslim cultural heritage-to musician collective Remarkable Current of Anas Canon, which initially shared the 'Islamic American tradition' by jazz, rock, funk and world music. ${ }^{13}$ The conditional view may also reflect perspectives of prominent Egyptian Islamic intellectuals, such as globally influential theologian Yusuf al-Qaradawi, towards developing a balanced vision of Islam that is neither extremist nor compliant, which has triggered the discussion on purposeful art (fann al-hadif) (Baker 2003, p. 22; Otterbeck 2008). Displaying affinity with Egyptian lay-preacher Amr Khaled and his ideas for improving (Islamic) society by means of distinct art forms, British singer Sami Yusuf, expresses related views in his internationally popular videos (Kubala 2005). This devout Muslim of Azeri and Iranian descent has considerably contributed to modernising the genre of Islamic nasheed, songs of praise a cappella or accompanied by a frame drum.

If art meets the requirements, i.e. distinction from the provocation of excessive behaviour in bodily movements, crude language, exciting rhythms and alcoholic consumption, those performing artists in the UK and the US who are (convert and born-again) practising Muslims stay rather convinced about the righteousness of their artistic practices. They know that Islam offers the possibility of a legal difference of opinion between the four Sunni schools of Islamic jurisprudence in case of topics that are not settled. Of these unsettled topics, music is just one. Moreover, as some artists emphasise, the Islamic legal spectrum is more nuanced than the haram/halal (prohibited or permitted) dichotomy of strict Muslims suggests, recognising human acts that are in the middle, neither rewarded nor punished. This view makes hilarious videos on serious topics possible, for instance those of Sri Lankan American M. Hasna Maznavi on the shame of praying publicly. ${ }^{14}$

Through the use of multiple definitions of justified conditions, the stance offers space for pushing the boundaries of religio-artistic conventions. The conditional view in the UK and the US may mean siding with scholars who have not found legal evidence that Muslims are prohibited to play music, act and dance, as well as siding with those who regard music with instrumental accompaniment to a degree permissible or even required. The staying-in-the-middle strategy offers a core position to depart from or get back to, which counts for a number of Salafi-oriented artists who think that art and music should be limited, as well as Sufi-oriented artists who think Islam and civilisation can impossibly develop without art and music (Fig. 1).

\footnotetext{
13 See also Curtis (2010). And: 'Jazz Messengers' (September 10, 2009). American Jazz \& Islam. Retrieved from: jazzislam.wordpress.com/ (accessed April 8, 2017).

14 Retrieved from: youtube.com/watch?v=ji5k3N6OW-8 (accessed December 20, 2017).
} 
The artists, who are well aware of the longstanding disagreements, may contribute to the public discussion on art, culture and Islam, thereby strengthening the position of selective authoritative voices or developing a voice themselves. On his website advocating art in Islam, ${ }^{15}$ African American performance poet Dasham K. Brookins aka Brother Dash sociologically explains the taste of the Prophet Muhammad as well as refers to recognised scholars with moderate arguments in favour of art, such as the late Mohammed al-Ghazali al-Saqqa, high officials of Islamic law in Egypt, or Grand Muftis, and Yusuf al-Qaradawi.

Despite his moderate stance in the discourse on art and Islam, al-Qaradawi, who recentres Islam for a global audience according to Mandaville (2007, p. 316), has acquired a controversial image in mainstream British and North American media based on alleged homophobic views and a certain sanctioning of 'wife-beating'. ${ }^{16}$ Concerning religious leadership, most Muslim performing artists have a taste for their 'own' American-born Islamic teachers, though disregarding that the views of prominent Western imams are significantly influenced on meta-level by opinions of the Islamic theological establishment in the traditional Muslim world.

The taste for indigenous religious authority among Muslim artists in the West is fed by the broad distaste regarding unqualified immigrant imams who are considered to mismanage British and American mosques through judging urban problems without understanding the identifications with popular culture among Muslim youths (see also Van Tilborgh 2016a). In the cultural landscape of imams creating cultural irrelevance by withholding critical and autonomous thinking, the growing popularity of literalist Salafism, politicised readings of Islam and the quiescent kind of South Asian folk Sufism, North American convert Hamza Yusuf has become a prominent advocate of orthodox Sufism, the scholarly and demanding form of classical Islam (Hamid 2008, 2009, 2016, p. 8). In the present study, Muslim American artists of indigenous and immigrant backgrounds, as well as several British artists, draw pride from the fact that Hamza Yusuf is considered the most influential intellectual Islamic scholar of the West, bestowing Western Islam with respectability. This former adviser of the White House and founder of the Islamic Zaytuna College in California—which aims to educate potential American Muslim leaders ${ }^{17}$ —may restore the linguistic, intellectual and cultural disconnect between the religious leadership and its audiences.

\footnotetext{
15 Dasham K. Brookins. Music and Islam: Wind, Strings and Fear of a Black Planet. Retrieved from: brotherdash.com/music-and-islam-wind-strings-and-fear-of-a-black-planet/ And: brotherdash.com/musicislam-abridged-version/ (accessed April 8, 2017).

16 Lybia in crisis. Retrieved from: guardian.co.uk/world/blog/2011/feb/21/libya-uprising-middle-eastprotests (accessed December 10, 2017). Bunting, Madaleine. 'Friendly fire'. The Guardian (October 29, 2005). Retrieved from: guardian.co.uk/world/2005/oct/29/religion.uk1 (accessed April 8, 2017). And: Barnett, Antony. 'Suicide bombs are a duty, says Islamic scholar'. The Guardian (August 28, 2005). Retrieved from: theguardian.com/politics/2005/aug/28/uk.terrorism (accessed April 8, 2017).

17 A Muslim liberal arts education. Retrieved from: zaytunacollege.org/about/our_mission/ (accessed March 17, 2012).
} 
Although Hamza Yusuf has a long track record of criticising 'Western decadence, injustice and impoverished spirituality', at some point after the terrorist attacks of 9/11 he did not want to contribute to any more 'them versus us' rhetoric ${ }^{18}$ and positioned himself against ranting extremist immigrants. ${ }^{19} \mathrm{He}$ defines musical productions as a kind of zakat, giving alms, which artists should practise by having the people around them benefit from their talent. Nevertheless, this Muslim leader takes care of guarding the conditions of art in Islam in the cultural contexts of the West, for instance by warning the artists, such as American born-again Muslim Omair Ali of British Indian and Pakistani descent, that there will be (too) many thresholds to be met in stand-up comedy: 'You will always have to push the limit.' Crossing boundaries could jeopardise the conscious Muslim attitude.

Generally, American Muslim performing artists who have not mastered Arabic completely, appreciate indigenous Islamic teachers over those from the Middle East. Especially in the phase right after conversion or having been born-again, when trying to seriously incorporate the customs of Islam, the artists feel related to these respected Muslim teachers and imams who once converted to Islam themselves. Indian American stand-up comedian Aman Ali, for instance, takes serious notice of one of their recommendations concerning his shows to put more serious content in his 'silly stuff'.

Besides Hamza Yusuf, North American Muslims Zaid Shakir and Umar Faruq Abd-Allah are considered part of the trend of learned Islamic teachers-all called sheikhs - born and raised in the West, who aim to establish a culturally relevant Western Islam that encourages socially and civically active behaviour of Muslim citizens in the present day society. Compared to Salafi-oriented teachers who focus on maintenance of the Muslim ummah, they understand the need for a more nationally tainted Muslim identity. Though explicitly distancing themselves from consumerism, materialism and individualism in the contemporary societies, the teachers recognise similarity in values and virtues among non-Muslim people, while at the same time elevating Muslim exclusiveness in ethics and morals. ${ }^{20}$ The translation to making Islam meaningful to a broader scope of people integrates customs in art and music.

African American imam and teacher Zaid Shakir, who is widely beloved among American Muslim artists upholding conditional and civilisational views, synthesises the religious disposition of not listening to music at home with the salient active recognition of the social and musical traditions of Black people (see also Van Tilborgh 2017).

American convert Muslim Umar Abd-Allah, holding a doctorate in Islamic Studies and Arabic, is engaged in the Nawawi Foundation, which produces teachings for America's growing Muslim population that are applicable to the modern day

18 Retrieved from: sheikhhamza.com/ (accessed November 17, 2014).

19 O'Sullivan, Jack. 'If you hate the west, immigrate to a Muslim country.' The Guardian (August 28, 2005). Retrieved from: guardian.co.uk/world/2001/oct/08/religion.uk (accessed April 8, 2017).

20 Hamza Yusuf, for instance, relates the requirements of submission and diminishing the ego in Islam with the pre-modern communal and non-waisting kind of society in American history at the Muslim Students Association event Constructing an American Muslim Identity at University of Louisville in 2006. Retrieved from: www.youtube.com/watch?v=h_lzMChv-Jk (accessed: March 21, 2012). 
world. ${ }^{21} \mathrm{He}$ stresses 'cultural relevance' as the core of the Islamic civilisation by using the metaphor of water, which reflects the historical relationship between various cultures and Islam. ${ }^{22}$

In history, Islam showed itself to be culturally friendly and, in that regard, has been likened to a crystal clear river. Its waters (Islam) are pure, sweet, and life giving, but-having no colour of their own-reflect the bedrock (indigenous culture) over which they flow. In China, Islam looked Chinese; in Mali, it looked African. ${ }^{23}$

In Umar Abd-Allah's view, ignorance of indigenous [Black] American culture reinforces the parochial understanding of universal Islam due to 'old world attitudes' of patriarchal Muslims. He pleads with Muslims to continue developing humour, literary and musical forms, film and theatre, which is an aspiration to Muslim distinction as well as an urgent request for a more self-confident civic attitude in order to gain cultural leadership. To counter the restrictive expressions of Islamism and Salafism, Abd-Allah's conception of Islam as water plays a significant discursive role among indigenous North American Muslim performing artists. Even the British and American cultural grassroots organisations Radical Middle Way (RMW) and Inner-city Muslim Action Network (IMAN), as explained by their organisers AbdulRehman Malik and Asad Jafri, have based their ideologies on Abd-Allah's writings in their artistic programmes to combine the cultural, spiritual and civic development of young Muslims. ${ }^{24}$ Muslims should not just be members of society, but active participants by using the tools of soft power in the domains of art and culture.

In sum, the conditional view, which means a rather restraint approval of art and music in the UK and the US, is related to the broad appeal of Islamic teachers, who, in trying to explain Islam in contextually relevant ways to adherents in the West, have revived classical, orthodox Sufism or 'Traditional Islam'. Eager to remain the powerful mainstream of Islam, the proponents of this renewed expression of religion have demonstrated the conditional view, which can thus be regarded to play a role in the contest between the transnational network of 'Traditional Islam' and the proponents of Salafism.

At the same time, the conditional view has brought the obvious presence of externally formulated moral criteria back in the field of art. As one of the principles of the field, the approval can be identified foremost by the goal to develop a society of Muslim cultural leaders. To improve the compromised Muslim image, this ideology also aims to normalise the representations of Muslims in the West by showing compatibility of Islam with the North American and British habitus. However, being

\footnotetext{
21 About us-Nawawi Foundation. Retrieved from: nawawi.org/?page_id=7 (accessed April 8, 2017).

22 Grounded in Pedagogy, cultural relevance means the empowerment of people to maintain cultural integrity (for instance regarding their specific cultural heritage), in order to improve their academic achievements.

23 Abd-Allah, Umar F. (2004, p. 1).

24 Radical Middle Way (September 28, 2011). Cultural Jihad: Making Islam Matter. Retrieved from: youtube.com/watch?v=QTQtYNIaoTI (accessed December 10, 2017).
} 
Muslim is not confined to praying in the mosque, but includes expressing Islamic values by distinctive preferences in art and culture.

While the network of 'Traditional Islam' may appear as a homogeneous network, the views on art of participating teachers differentiate from the attitude of cautiousness to the attitude of support and stimulation in vertical, top-down, as well as horizontal, friendship, relations between teachers and artists. By mediating Islam and the modern day world, the conditional view has a reformist approach, but, in providing a more purified scope for ordinary believers, also meets the traditionalist perspective by justifying and elaborating several traditional forms of Islamic authority. Being connected to indigenous leaders with significant cultural and symbolic capital in the transnational network of 'Traditional Islam' has made the artists feel part of an important development within Islam. It stimulated Muslim platforms, providing opportunities for Muslim artists to perform on their own non-Hollywood kind of terms, increasing their power to define (Van Tilborgh 2016b, 2017). Nevertheless, although Islamic moral guidelines are, for many artists, an important aspect and the conditional view their foundation, it is not their final stage. In the process, the normalising aspect and the urge to artistically professionalise may become as, or even more, important as being religiously distinctive.

\subsection{The strict view}

In the strict view, art anticipates on restrictions deduced from religion. In the present field of art, the strict view partly, yet evidently, relates to the conditional view but advocates clearly defined boundaries that 'limit art and music' (Fig. 1). Aware of the conditions for appropriate and decent content, in their quest for the most legitimate practices that align the fundamentals of Islam these male Muslim performing artists try to stay away from the use of controversial (string and wind) instruments. They might even dismiss all musical accompaniments-except for male reciting and singing. The artists tend to shun Muslim dancing performers and Muslim female singers in particular. Criticising any mixture of culture and religion, they regard, for instance, the habit among (Pakistani) immigrant Muslim women to just partly cover their hair a religiously mistaken ethnic practice. Of those upholding the strict view, particularly British Muslim performing artists are eager to avoid getting messed up in the disputed area between the obviously halal and the obviously haram in case of art and music (Van Tilborgh 2017). Safeguarding themselves from doubt, they turn from the genre of rap to the genre of spoken word or a cappella singing, developing a taste for the locally inauthentic form of traditional nasheed.

Generally, the artists of the strict view refer to the legitimate founding fathers of the Sunni schools of Islamic Law from Muslim intellectual history, Abu Hanifa, Malik ibn Anas, Mohammed al-Shafi'i and Ahmad ibn Hanbal. Particularly in contrast to artists following the 'civilisational view', they interpret their judgement of music as a collective condemnation of musical instruments-except for the hand drum, the daff_-based on forbidden innovation in Islam, bidah. ${ }^{25}$ At the same time, artists

\footnotetext{
${ }^{25}$ Arts \& Islam Hip Hop Debate. Retrieved at: islamhiphop.blogspot.nl/2008/06/islam-and-hip-hop-by-
} shaykh-michael_6059.html (accessed April 8, 2017). 
of the strict view emphasise the need to worship God over 'worshipping a sheikh' and therefore reject to choose just one of the four schools of Islamic jurisprudence. The rejection of the mediation of schools of thought characterises literalist Salafism (Hamid 2009, 2016). Regarding contemporary exegesis with respect to art in Islam, the artists have gradually turned away from the moderate approach of prominent Yusuf al-Qaradawi. Instead, they have come to appreciate one of the leading representatives of the conservative Saudi Arabian religious establishment, Muhammad ibn al-Uthaymeen (d. 2001). According to Hamid, Salafi adherents in the West refer to al-Uthaymeen's unprecedented views in order to criticise Muslims with a weak command of scholastic frames of reference (Hamid 2009, 2016).

Several artists of immigrant (e.g. Caribbean) background and White indigenous artists - convert and born-again Muslims—-share Salafi-influenced views. For Salafi adherents, doctrinal clarity and moral fortification are the conditional basis of collective transformation (Hamid 2016, p. 53). In the present study, the artists find these in a number of Salafi-oriented teachers who judge the use of musical instruments as jeopardising the chance to get to Paradise. This restriction arouses the mental sense of particularly Muslim artists regarding the possibility of being elected to salvation in the hereafter (Van Tilborgh 2016a). The Fundamentals of Tawheed of Bilal Philips, about the one-ness of Islam, had a broad appeal (Hamid 2009). Jamaicanborn Philips, who was a lead guitarist in a rock group once, left the kind of music behind that is produced by 'wind and strings' due to his new conviction that musical instruments are sinful. ${ }^{26}$ On the Internet, he explains to the artists that the trajectory 'from darkness to light', i.e. from the state of ignorance to the state of truth, is the way to become members of 'the Elect'. Stimulated by authoritative figures, the artists of the strict view believed they could reach this position by limiting their artistic endeavours. This idea has triggered their phase of 'intensified formalisation' with respect to cultural manners, habits and tastes (Van Tilborgh 2017). In this kind of trajectory, one of the superior examples for both preachers and artists is al-Hajj Malik al-Shabazz, aka Malcolm X. He developed, after two spiritual conversions, from petty criminal to an internationally prominent Islamic speaker.

Together with the influence of Islamic channels and temporarily present Salafiinspired lecturers in the UK, British Pakistani imam Abu Hasnayn Murtaza Khan may have contributed to the taking of a stricter view to art and Islam in the case of British Caribbean rap artist Masikah Feesabillah. Masikah, from a Saint-Lucian Jamaican family, whose brother was murdered by a youth gang, had been involved in drug dealing, just like Malcolm X, at the start of his career. Khan delivered prevailing anti-music arguments at the debate Singing or Sinning in 2009. ${ }^{27}$ While convert Muslim Masikah performed his spoken word act wearing jeans in saggy style at the London meeting, the imam discussed jeans below the waistline of youths in hip-hop culture as a symbol of Western moral decline. ${ }^{28}$ Several months before attending

\footnotetext{
26 www.youtube.com/watch?v=4Y8KakzkoZ0 (accessed August 24, 2015).

27 Music-Singing or Sinning, organised by Salafi-oriented performance poet Lori Zakariyya King, was part of the Express Yourself conference in the London Muslim Centre of the East London Mosque, 2009.

28 Blog visitor Uzaman 901 underlines Khan's view. Retrieved from: campusalam.org/contributions/2009/Jun/17/ singing-or-sinning-murtaza-khan-vs-usama-hasan.html (accessed March 23, 2012).
} 
Singing or Sinning, Masikah already considered quitting the use of instruments at some point in his religio-artistic career. Referring, among others, to the Islamic schools of jurisprudence, he 'could not go against what the scholars unanimously agreed upon'.

Sometimes I find it difficult to memorise more Qur'an, because of music. It's just you can't put both of them in the same cup. [...] I don't say whether it's allowed, or whether it's wrong, because that topic [...] It's not black and white. [...] While also in Islam, they say if something is a grey area, then keep away from it.

Reflecting on the Islamic 'distraction argument' concerning the focus on Allah, the rap artist abandoned musical instruments in 2010. Khan's speech on music as a seductive tool towards Muslims of the promiscuously perceived West may have been decisive.

The appeal of Salafism and its moral fortifications could be understood as follows. Several artists of the strict view have lived in or near less stable environments experiencing themselves or others nearby as threatened by criminality and/or sociopsychological problems. In their performances, they focus more obviously than other artists on moral rules concerning sexuality and family life. They tend to regard the Islamic culture, as they perceive it had been present in the time of the Prophet, as one of the few positive expressions of culture.

According to Lamont, to keep disorganisation and danger at bay, people tend to draw strong moral boundaries when the boundary between them and lower classes is more tenuous than for those in better socio-economic circumstances (2000). Besides, Muslims who discursively decouple culture and Islam tend to identify negative cultural experiences with the concept of culture itself in order to make space for a religion that consists of a 'pure Islam', which offers them safety (Van Tilborgh 2009).

Challenged as well by the social London Salafi environment to get into the Islamic readings properly, artists of the strict view decided to better be safe than sorry by following the religious warnings, accommodate their dress and movements and abandon musical instruments as expressions of their religiosity. Exchanging their names with those having religious status, they left the field of art, or continued with performances of nasheed or autobiographical acts in spoken word rap rhythm. Following the trajectory of Malcolm X in the narratives that they produce, several artists, such as British-Jamaican Ashley Chin, aka Muslim Belal, have become internationally invited Muslim motivational speakers, warning youth about street culture and the deceptions of fame. The adaptation of Malcolm's 'from hell to heaven' narrative fits the idea of being able to belong to the ones who are chosen (Van Tilborgh 2016a).

The strict view of Muslim performing artists in the UK and the US resembles the hard-line view of authoritative voices in the Arab world concerning art in Islam, but leaves out violent practices and displays a lot of religio-artistic differentiation. Although considering himself on the side of those who are 'weary of music', British Bangladeshi graffiti artist Mohammed Aerosol Arabic Ali began, in the course of time, to underpin his shows of graffiti spraying with poetry performances and, subse- 
quently, with percussion. In his creations of multi-media experiences, the artist now explores alternative ambient 'sound'. The experienced spiritual boundaries have transcended into artistic boundaries, because, electronically, Aerosol Arabic produces 'music without making music'. At his show Breaking Down the Wall at the Herbert Gallery, in which he compared the German bombings of the Coventry Cathedral with the bombings on Palestine, the soundscape emanated from unrecognisable recordings made at the Hajj pilgrimage to Mecca and the adhan, the call for prayer.

Due to their style of Arabic and Islamic symbolism, in which visible faces are excluded, the initial sprayings of Aerosol Arabic, such as Unity, Brotherhood and the furious Free Gaza graffiti mural in the suburbs of Birmingham, were not particularly anchored in British or Western culture. When artistically developing, his art works became less outspoken, multi-layered and as much inspired by historical local and Western culture and literature. In the course of time, he preferred to cooperate with avant-garde non-Muslim poets, singers and percussionists whose artistic quality went beyond those of new British Muslim artists.

In sum, Muslim artists with the strict view draw on specific classical scholars and contemporary conservative Islamic teachers. Relationships between Salafi-oriented teachers and artists do not seem to be composed of the traditional vertical nor horizontal kind of bonding. Their cultural tastes align with preachers having experienced a tough life, who produce their messages in strong terms and perceive Muslim human rights activist Malcolm X as an authoritative example. Malcolm's 'from hell to heaven' trajectory has given the artists a sense of being able to develop cultural-religious capital and Muslim power without academic certifications. From a pressing Salafi-disposition to the requirements of salvation regarding the afterlife and feeling responsible to raise those who may end up in the gutter, artists of the strict view tend to become Muslim 'messengers' in mission-like performances in which they imitate as well as develop some kind of authoritative voice themselves. Using morality in their work, they tend to fill the niche that has emerged through the fragmentation of Islamic social authority in the West by explaining the dos and don'ts of Islam. The Salafi-stance represents not only the literal understanding of Islam, but also the reformist kind of orientation. Leading to emancipation from a socially and culturally destabilised or deprived environment, in several cases, their new strictness has come to enhance their status.

While trying to remain on terms with both the convictions of orthodox Muslim audiences and personal idiosyncratic Salafi-inspired ideals, in order to meet new audiences and enlarge their social and cultural capital, several Islamically strict artists develop their careers by pushing certain religio-artistic boundaries. As they improve their artistic insights and skills in the course of their careers, some artists cultivate a closer relationship with the field of art and broaden their views to religion that were once quite strict, whereas others may quit the performing arts altogether.

\subsection{The civilisational view}

In the civilisational view, culture and art are integral to religion. Compared to the views of authoritative voices in the art and Islam debate in the Muslim world (see Otterbeck 2008, 2016), the civilisational view is a new perspective. Muslim perform- 
ing artists with this view are convinced that Islam needs art and music because it are cultures that take Islam forward in terms of the level of civilisation (Fig. 1). The view that 'civilisation and Islam need art and music' is based on interdependence: Islam cannot sustain without human beings, and human beings can only blossom through the development of their cultures. Muslim performing artists with this orientation are predominantly converts to Islam, often from mixed African descent, and tend to share a disposition to Sufism. Although their views are based on the balanced, conditional view to art and music, they stress much more strongly that there is no way of spiritually denying art. African American performance poet Amir Sulaiman explains:

Art gives an outlet to voices and ideas that don't have another place. This is why art is sacred and essential in society. ${ }^{29}$

Because art is necessary to reach enlightenment, according to these Muslim artists, music, theatre and dance are integral to all cultures. This perspective is brought to the fore by filmmaker Mustafa Davis, of mixed African American and White ethnicity, in the documentary film Deen Tight. The film portrays Muslim performers in the West and their struggle to harmonise their musical practice of singing, jazz and rap with Islam. More specifically, the film tends to make clear that art and music are integral to African American Black cultures. Rasheed Ali, one of the performers, delivers the film's passionate key quotation:

If you don't have music, and you don't have dance, you are lacking something fundamental as a human being.

Generally, cultural orientations that people hold tend to be influenced by their fields of study (Van de Werfhorst and De Graaf 2004). Some of the artists who express how art is naturally related to Islam have followed formal art or socio-cultural studies. For instance, African American theatre director and actress Cristal Chanelle Truscott achieved her doctoral degree in Performance Studies, African American rap artist Tyson Amir attended African American Studies and British Jamaican rap artist Sukina Abdul Noor Caribbean Studies. These kinds of studies may have reinforced the already present cultural tastes from the kind of habitus that was constructed by the cultural pasts of their ethnic communities.

Muslim performing artists of the civilisational view are self-conscious about being related to the originators of leading musical styles - from jazz to hip-hop - that derived from the songs putting people through the misery of slavery. ${ }^{30}$ Moreover, African American Muslim artists grew up in an environment of social activist parents, who used various forms of art in the Civil Rights and Black Power movements to battle racism and gain legal rights. A number of these mothers and fathers earned their living entirely in the cultural sector, for instance as professional musicians. Informed by the transmission of cultural capital from upbringing and education,

\footnotetext{
29 Emel, the Muslim Lifestyle Magazine, January, 2009.

30 See also: Michael Mumisa (June 13, 2008). 'The link Between Islam and Hip Hop'. Arts \& Islam Hip Hop Debate. Retrieved at: http://islamhiphop.blogspot.nl/ (accessed March 13, 2018).
} 
the disposition to see art and faith as a necessary entity for humanity is central to Muslim performing artists upholding the civilisational view.

Many artists of the civilisational as well as conditional views have outspoken ideas about the opponents of art and music who are purging Islam of considered non-Islamic impurities, bidah. They experienced how American Muslims tended to regard the very strict Muslims as authentic Muslims because of their descendance from Mecca and Medina. Infiltrating the UK and the US with an abundance of Saudi oil money, the Wahhabis and Salafis are considered of going to the edge of the religion in order to bring a more extreme view into the moderate centre of Islam. Besides, Black Muslim performing artists often meet anti-music tastes among the more conservative (South Asian) immigrants. The artists understand these as racist preferences, embedded in the habitus of people who have incorporated inauthentic prohibitions in Islam deriving from their ethnic frames of reference ('cultural baggage'). In return, several artists distinguish themselves from the 'identity art' of new immigrant Muslim artists or show disdain for the soft, religious kind of nasheed from abroad, which are specifically appreciated by the dominant conservative Islamic institutions. These issues are raised, such as by Dasham K. Brookins and Tyson Amir, in poems and raps.

Artists of the civilisational view have valuable personal ties with Islamic teachers who passionately regard integrating artistic culture highly necessary in order to enlighten the community and renew Islam as a civilisation. While the conditional view supports modernised forms of poetry and storytelling as a legitimate way to combine art and spirituality, Islamic teachers of the civilisational view also approve more obviously of jazz and Westernised forms in the hip-hop of Muslims. Specific expressions of rap music, MCing, spoken word and hip-hop theatre are believed to derive from the poets in the time of the Prophet Muhammad. This perspective holds that the rhythms of their conscious kind of poetry have made them the first Muslim 'conscious rappers' ever, because this music invited people to Islam and proselytised. Teachers involved regard these art forms to reflect the socially active spirit of Islam, which aims, in their view, for social justice and equality more than any world religion (see also Jackson 2009; Mohaiemen 2008).

One of these teachers is British South African Michael Mumisa, a scholar at the University of Cambridge, who has been a spiritual mentor in hip-hop for several Muslim performing artists, such as British Nigerian Rakin Niass and British Mozambican Mohammed Yahya. They have drawn legitimation for their expressions from his Arabic translation of Fatwa on Music by the Grand Mufti of the Al Azhar University in Egypt. ${ }^{31}$ Mumisa criticises the dominant pietist form of Sufism as introduced by immigrants from Pakistan to have marginalised the Muslim position in British democracy. Next to practising Islam as a spiritual exercise, he promotes the alternative (indigenous American) form of Sufism by 'social engagement in a more radical

\footnotetext{
31 Michael Mumisa Alimiyya. 'Fatwa on Music by the Grand Mufti and Shaykh of Al-Azhar'. Islamictext Institute. Retrieved from: islamictext.wordpress.com/music-azhar-fatwa/ (accessed April 8, 2017).
} 
political way', which brings Muslims ahead in society as critical citizens. ${ }^{32}$ In this active kind of Sufi way, Muslim rap band Mecca2Medina has fought against racism with their songs.

In particular imams with (past) personal artistic activities in jazz and theatre are recognised as individual mentors with respect to the spiritual dimensions of being a Muslim performing artist. African American Al Hajj Talib Abdur-Rashid, imam of the Mosque of Islamic Brotherhood in New York-the lineal descendant of the Muslim Mosque Inc. started by Malcolm X-is one of those teachers supporting the distinctive genre of hip-hop. Having a trajectory of taste for Pan-Africanism and Black Nationalism, ${ }^{33}$ convert Muslim Abdur-Rashid preaches civilising notions by encouraging Muslim listeners to take pride in their Muslim behaviour through distinguishing themselves from certain habits of (assimilated) immigrant Muslims and non-Muslims. 'Hip-hop imam' Talib stresses the goal of the Muslim African American identity.

Muslim artists have to decide: 'Am I going to call people to the hell fire or am I going to call them to Paradise?' [...] I push for them to be distinctive: Don't blame them, be yourself, be distinctive. Distinctive to non-Muslim artists and distinctive as African American artists.

American convert Muslim Johari Abdul-Malik, director of community outreach for the Dar Al Hijrah Islamic Center in Northern Virginia, ${ }^{34}$ has supported hip-hop expressions of Black British Muslim artists by invitation of RMW to the series Spitting Light, Healing the Hood in the UK. ${ }^{35}$ The imam, of African American and Caribbean descent, acts against restrictive views among Muslims when these are disadvantageous to the participation of female artists. ${ }^{36}$ When a Muslim brother complained about singing women on stage, sheikh Johari educated him:

In this context, when we're singing about Allah, when we're singing about the Prophet, when we're singing about goodness, when we're singing about oppression, when we're singing for justice, when we're singing for peace, this isn't just allowed-this is something we should encourage! ${ }^{37}$

\footnotetext{
32 See also: Michael Mumisa (June 13, 2008). 'The link Between Islam and Hip Hop'. Arts \& Islam Hip Hop Debate. Retrieved at: islamhiphop.blogspot.n1/2008/06/islam-and-hip-hop-by-shaykhmichael_6059.html (accessed April 8, 2017).

33 Eisenberg, Carol (January 22, 2005) 'Black Muslims seek acceptance from fellow Americans, adherents'. Faith and Values. Retrieved from: seattletimes.com/html/faithvalues/2002157825_islam22.html (accessed April 8, 2017).

34 Johari Abdul-Malik. Retrieved from: imamjohari.com/imamjohari.com/Media-About_Me.html (accessed February 15, 2015).

35 April 26, 2009, at Buckinghamshire New University, High Wycombe, London, UK.

36 'Imam Johari Malik \& Imam Talib Abdur-Rashid on Zawahari's Statements on Obama'. MuslimMatters. Retrieved from: muslimmatters.org/2008/11/22/imam-johari-malik-imam-talib-abdur-rashid-onzawaharis-statements-on-obama/ (accessed April 8, 2017).
}

37 According to Abdul-Rehman Malik (London, November 5, 2010). 
This adjustment regarding the equal position of women lays bare the core of the civilisational view-that of activism through art. This view also holds that Muslims in art could stimulate the process of intellectual struggle, ijtihad, in the UK and the US, as well as the renewal of the Islamic experience in Muslim-majority countries, 'where people are unable to keep up with modern times'. Nevertheless, according to this line of reasoning, the talents of the artists engaged are restrained by imported imams who practise outdated ethnic conceptions, which marginalise African American and British Caribbean groups in Islam. With this stance, Islamic teachers alike paint a picture of cultural attitudes belonging to a Muslim new world versus those that belong to a Muslim old world in the overall Islamic community.

In the previous century, the 'holy protest against racism' has given Blackamericans a sense of Islamic ownership by mediation of several proto-Islamic organisations, such as the Black nationalist Nation of Islam (Bukhari et al. 2004; Jackson $2005,2009)$. This wayward sense has been largely erased with the influx of immigrants of Arab and South Asian Muslim-majority countries after 1965. Blackamericans came under the influence of Muslim immigrants through the importation of imams who were not, or in a negative way, familiar with North American customs and culture. Explaining restrictiveness to forms of art rooted in comprehensive antiWestern tastes, Muslim artists and teachers of the civilisational view are aware of the writings of Abd-Allah, who discusses the 'old world attitudes' in an academic way, but also of those of African American Islamic scholar Sherman A. Jackson. Although less an adviser of Muslim performing artists as the local indigenous imams 'Talib' and 'Johari', Jackson concludes:

The result has been a cognitive dissonance in which fossilized doctrines and practices from the Muslim world are imagined to be viable substitutes for effectively engaging American, and particularly urban American, reality (Jackson 2009, p. 44).

From Jackson and Abd-Allah, indigenous Muslim artists learn that Blackamerican convert Muslims have given Islam the status of 'bona fide American religion', because their conversion to Islam connotes neither cultural nor ethnic apostasy. Convinced of once having brought Islam to the West, they do not need to be ashamed of their ethnicity nor of their activist culture considering that, by acting in the name of justice, Prophet Muhammad is one of the first activists. Referring to the Blackamerican experience, in this perspective, Islam does not require cultural customs to be abandoned in order to become subservient to other ethnic (Arab or South Asian) customs. Although, as Moosavi observed, convert Muslims regularly adapt their behaviour expressed in naming and dressing to gain the blessings of born Muslims (2012), Muslim American hip-hop artist Aja Black quit the abandoning of her free style and authentic cultural tastes after entering the phase of controlled informalisation (Van Tilborgh 2017). 
While American Muslim performing artists of the civilisational view tend to prefer indigenous American Islamic teachers, British artists with similar view also appreciate the religio-artistic advice of spiritual leaders from West Africa. ${ }^{38}$ These imams, such as late Ibrahim Niass and current Ahmad Tijani bin Ali Cisse of Senegal, leader of the Tijaniyya Sufi Order, ${ }^{39}$ reflect West African culture in their teachings. Adherent artists believe that, although people were religiously taught by eminent female scholars in the beginning of Islam, 'cultural notions of Arab and Pakistani culture' have taken over since then, resulting in a permanent situation that has 'put women in the background'. This attitude is considered to be in contrast with the elevating way West African culture treats women.

In sum, Muslim artists with the view that Islam needs art and music draw on an important number of contemporary Islamic teachers. The latter tend to be Sufidisposed, principally in the more activist way, regularly affiliated to the transnational network of 'Traditional Islam', and often born in or related to the West. The relationships between performing artists and teachers imply a horizontal (friendly) kind of bonding. The artists involved are regularly crucially supported in their artistic activities by moral sanction of their imams. These stakeholders in the field of art advocate that mastering the culture may only be possible through distinguishing oneself from manners of the established Muslim world. Although based on the partly conservative conditional view, the civilisational view displays a stronger reformist perspective by justifying less of the traditional kind of authority deriving from Muslim-majority contexts. Mediating Islam and the modern day world, it expresses that some traditional institutions of Islamic authority ought to be revised while alternative indigenous institutions ought to be recognised. By more obviously stressing the value of activism through the arts, the civilisational view tends to represent an imagined (Black) Muslim community of citizens who seek public recognition for cultural distinction from a dominant strand in religiosity in the overall Muslim community. More than seeking universal claims, through the particular histories of their communities, the civilisational view represents the local and national embeddedness in cultures and indigenous contexts.

\subsection{The secular view}

In the secular view, art and religion belong to different domains of life. Upholding the view that 'art and Islam should be separated' (Fig. 1), Muslim performing artists approve of musical instruments and women on stage without hesitations and perceive the art and Islam debate as ridiculous, or as something that is opposite to their personal conception of Islam. These artists tend to regard religious faith as part of their private lives that needs no spiritual expression on public stage. Although their comedy is not explicitly sexualised, they do not reinforce external moral criteria

\footnotetext{
38 For instance Rakin Niass, who himself encourages British female Muslim rap music. Imam Sheikh Tijani Cisse Track by Rakin Niass (June 6, 2013). Retrieved from: youtube.com/watch?v=g-z4nxYlthk (accessed April 8, 2017).

39 Retrieved from: themuslim500.com/profile/sheikh-ahmad-tijani-ali-cisse (accessed December 10, 2017).
} 
concerning sexuality and family life to frame the content of their comedy. Generally, they have a less orthodox understanding of practising their faith. Bearing immigrant histories, artists of the secular view are born into South Asian or Middle Eastern Muslim families, or represent this kind of lineage to their audiences. Some of them have been brought up in the South Asian kind of Sufi tradition, also called 'cultural Islam'. Off-stage, they may display affiliation for (secularised) Sufism to a limited extent and hardly refer to Islamic teachers to base their opinion upon regarding their artistic approaches.

Starting with the terrorist attacks of 9 September, 2001, and 7 July, 2005, in the US and the UK respectively, artists with immigrant Muslim backgrounds were drawn into the global discussion on Islam in relation to terrorism, the treatment of women and democracy. While the attacks triggered many Muslims to take the side of Islam more obviously by expressing the conditional view, the attacks also generated unexpected opportunities for (female) artists of immigrant descent to give shape to their identities and improve their image in the public domain. They became able to repay by means of stand-up comedy what they had gone through as outsiders in the West. In particular, those artists who had felt socially excluded in their youth-for example due to the American memory of the Iranian Islamist hostage of the American Embassy starting at 1979, being identified as Arabs, or, more generally, having foreign names, features and accents that were not socially appreciated in the West-managed to capture platforms to spread their views after $9 / 11$.

Whereas artists of the secular view sometimes reflect the cultural taste of the nonMuslim established, they convey critical considerations with regard to both their White visitors and their educated visitors with comparable immigrant backgrounds. Although not specifically taking care of the sensibilities of Muslim audiences in the way artists with the conditional view do, they similarly discuss integration and terrorism from their Muslim identity, which was highlighted in the years after the attacks. The artists poke fun at how Muslims structurally are stigmatised by nonMuslim people and institutions in the West, treating ordinary Muslims as potential terrorists. However, they simultaneously satirise how Islam has become represented by conservative or fanatical factions of Muslims since the global Islamic Revival, for instance when Sajeela Kershi questions whether sexy underwear would fit the hijab. ${ }^{40}$ Vitalising their 'ethnic capital' drawn from membership of the Muslim South Asian or Middle Eastern (Pakistani or Egyptian) networks, the artists tend to treat topics with self-irony from the angle of their ethnic cultural identity, ranging from particular manners in moving the hips to physical punishment in the mosque. British Pakistani Jeff Mirza, for instance, recounts how his imam used to hit him when he was still a kid. ${ }^{41}$ Because some community members may accuse or even attack the artists by reason of airing the dirty laundry in public, soiling the nest and thus degrading Islam while making use of the visible Muslim identity in dress (hijab or niqab) on stage, following the view to separate art and Islam may thus also be motivated by reasons of security.

40 Sajeela Kershi at Oliver's Music Bar, London UK, August 1, 2009.

${ }^{41}$ This is How We Role. At Richmond upon Thames College, Twickenham, UK, March 28, 2009. 
Although Muslim stand-up comedians are also encountered among those expressing the religio-artistic conditional view, such as the comedy group Allah Made Me Funny, the secular view is particularly present among artists in comedy, and to a limited extent in critical theatre. Notwithstanding that artists with the secular view value art from the perspective of free expression, the entertaining aspect of cultural productions is usually more important to their cultural capital than the artistic aspect, which is congruent with the characteristics of the genre of comedy.

The artists do not seem to be passionately engaged in the art and Islam polemics. Some of them have not experienced controversy in this matter very close to their personal lives. They may have made a late entrance in the field of art as Muslims, or have been brought up in a cosmopolitan disposed, socio-economic affluent immigrant family with liberal orientations. Other artists, in contrast, have managed to distance themselves from the cultural-religious restrictions of their parents and socio-economic less affluent environments. Particularly, they had to rebel against the Muslim (Pakistani) immigrant habitus when displaying distaste towards rap music, theatre and acting, from perceiving these as low culture. Professionalisation towards becoming an all-round comedian in their careers is one of the means to bring independence from their milieus and from being exclusively identified as a Muslim artist. Creating a balance between religious and cultural ties is part of this process. After almost ten years of experience in stand-up comedy, British Pakistani Shazia Mirza explains the composition of her identity: 'I am a comedian. My faith is just one little bit of me.'

Due to the many Muslim-identified terrorist attacks and experienced comparisons between the West and its Enlightenment and the Middle East and its Islam, ordinary Muslims have to deal with degrading depictions deriving from the dichotomies of good (secular, civilised, Westernised) Muslims versus bad (premodern, fanatical, barbarian) Muslims (Mamdani 2005; Morey and Yaqin 2011). Comedians with Middle Eastern and South Asian backgrounds satirise East-West notions, raise awareness of played-out oppositions as well as point at similarities. Morality is questioned where human hypocrisy is concerned both in and outside the Muslim community.

While the intentions of comedians of the conditional stance are mostly quite clear to practising believers, the irony of the secular stance is, however, multi-layered and less clearly positioned, triggering laughs by creating embarrassment or confusion. Egyptian American Ahmed Ahmed, born into Islam, displayed this ambiguity after encountering a Dubai mosque opposite to a nightclub. The contrast between the transcendental sound of the muezzin calling Muslims to Islam and the idea of pop music calling young people to the disco, made the comedian share a possible doubt: 'Should I dance or should I pray?' ${ }^{2}$ British Pakistani Shazia Mirza informs her audience that, according to her father, 'the worst thing is to marry a Black man' ${ }^{43}$ Some beholders understand this line as treating the subject of racism in certain Muslim communities. Others perceive this, nonetheless, as a racist insult.

42 Just Like Us, movie of Ahmed Ahmed. At Village East Cinema, NYC, US, April 26, 2010.

43 At Comedy Camp, London, UK, March 24, 2009. 
In sum, the vision that art and Islam should be separated partly resembles the dominated liberal view of authoritative voices in the art and Islam debate in the Arab world, which tends to reject censorship in the domain of art. Performing artists of the secular view have tried to gain a certain relief from faith but without altogether falling into atheism. They could be identified as being positioned between the young professional Muslims who aim to develop the Islamic identity and the first-generation immigrant Muslims who have tried to gain social acceptance by distancing themselves from Islamic practices.

Most artists in this category do not hold specific ties with the field of religion or may even avoid these relationships. The sources for their artistic practices are famous non-Muslim comedians, who may have pushed the boundaries in comedy. Still, the secular view is not radical in challenging the very foundations of the corpus of religious knowledge. Compared to artists of the conditional view, however, by serving a broader spectrum of audiences in non-Muslim contexts, among which gay audiences, these Muslim performing artists indirectly react to authoritative voices and challenge conventional cultural tastes in their communities.

\subsection{The artistic view}

Lastly, in the artistic view, art and religion are combined in an unconditional and reciprocal way. Muslim performing artists with the artistic view are particularly eager to 'liberate art from restrictions'. They argue that the creation of art is intrinsically impossible when conditional and under restrictions, no matter what kind (Fig. 1). At the same time, they practise and explain art in a way that is, to different degrees, informed by their way of Islamic faith, which seems especially shaped by regularly reflecting on Islamic conditions considered to be imposed on art and other issues. These performing artists are mainly of immigrant descent, i.e. born into Islam and born-again Muslims, who approve of art, musical instruments and female performers on stage. They argue that, according to the Quran, good Muslims should be questioning and revisiting faith at all times. Muslims could even grow as adherents of Islam through developing in the field of (popular) arts-debate and negotiation being at the heart of all things - meanwhile producing alternative visions to Islam. Based on the belief that all people are equal, a topic could be the re-institutionalisation of the absence of hierarchy in Islam.

The artistic view observes relations between dissidence and Islam as part of the religion. Similarly, it provides room for reflections on sexuality as an integral aspect of Islam. Artists who aim to liberate art from restrictions are critical towards static perspectives of Islam, which they encounter among other Muslims when artistically denying that the first question should be: 'How is the best way to express something?' They reject the attitude to start from ready-made definitions about what is Islamically allowed and what is illegitimate regarding art.

Several contemporary Muslim performing artists display conceptions of a comprehensive, inclusive Islam, which displays pluralism by respecting a variety of visions. Compared to the liberal view of authoritative voices in the art and Islam debate in the Arab world, which, at its best, tends to tolerate competing outlooks and rejects censorship in the domain of art, the artistic notions of several contemporary 
Muslim performing artists may be theologically more far-reaching. Therefore, the status of some of these British and North American artists has been prone to much discussion in the Muslim communities of the UK and the US.

Unlike artists of the civilisational view, several artists of the secular and, to a greater extent, artistic views have experienced little encouragement or even discouragement from their parents to participate in the arts. In terms of cultural capital, the latter contemporary artists may also have benefited negatively of the new opportunities experienced in the field of British and American Muslim performing artists by becoming exclusively labelled as 'Muslim artist'. They are the most diverse category in the structured field in terms of individualised views to art and Islam. Displaying some relatively radical aspects, the artists explain their considerations with passion and, sometimes, even anger.

British Pakistani actor and director Hajaz Akram, who has often worked for mainstream film productions, believes that making art from within whatever confinements is a 'scaring and dangerous' attitude. He is worried that Islamic theatre in the West, which is supposed to connect immigrant Muslims to their cultural heritage again, creates more boundaries than effaces them.

I think my faith in a sense drives to a certain degree what I do. But I also totally believe that as an actor I should be allowed to put what God says to the test. [...] I think that's what theatre is all about: to certain degrees being able to put these things to the test. Such as what it is to be a Muslim in modern day society; [...] what kind of interactions happen within communities; [...] things that have to do with praying five times a day, drinking alcohol, being a virgin or not a virgin; all of those things that are real. [...] You can't just say this is what you should do and this is how you should behave. No, [...] you have to make an informed choice about it.

Similar ideas could be found in the environment of Naz Koser, British Pakistani born-again Muslim and creative director of, at the time, socio-creative enterprise Ulfah Arts.

The avant-garde artist of the life art installation Too Punk to Pray is familiar with the severe British Muslim criticism to her Sufi Punk productions, which led to her conviction that 'Only those who don't have God have fear of losing Him.' The kind of socio-autonomous theatre, as Ulfah Arts was meant accordant with the central ideas of Koser, should use no halal or haram in its operating principles. The enterprise intended to provide the (Muslim) women who participated in its projects the space to explore and negotiate religio-artistic parameters instead of focusing on the considered impermissibility of musical instruments. This conviction displays no room for fear by putting art, in its immediate relevance, before faith: If Muslim artists were to start creativity from spirituality, there would be more than just one correct answer when questioning musical instruments or singing Muslim women. Based on the fundamentals of respect and structural negotiation about meaning, Muslim-driven theatre could even bring about enough tolerance for 'sex in a lyric'. 
London contemporary artist Yara El-Sherbini, from Caribbean and Egyptian descent, creates performances of artistic British 'pub-quizzes' in art houses. This concept drives audiences to reflect on the assumed opposition between religions, for instance through recalling the Ten Pillars of Islam.

Every Muslim would say: 'There aren't ten pillars-there are five.' [...] No, there aren't five pillars of Islam. The Five Pillars of Islam actually are not found anywhere in the Quran. What is found within the Quran, are the Ten Commandments [...] about how we should live our life. They are present in the Quran, and they say: 'Follow these.' Somebody has looked within the Quran, [...] put them together and said: 'These are the Five Pillars.' [But] Nowhere in the Quran does it say that.

Similarly to El-Sherbini questioning the generally alleged content of the Quran, American Pakistani Basim Usmani discusses interpretations of Islam. In his expressions, the bassist and vocalist of The Kominas applies the anarchist style of Taqwacore, which amalgamates the Arabic word taqwa (piety or God-fearing) with 'hardcore' (punk) music, a subgenre of Muslim-related punk. The lyric Suicide Bomb tha Gap ${ }^{44}$ stresses that Islam is positive about sex, considering the degree of 'shag' liking of Prophet Muhammad. Muhammad was a human being after all, who-like other people-'pissed, farted, sinned and got corrected'. The Kominas represent dissident artists who are kicked off stages by Muslim institutions. This way, they create space for young Muslims to introduce alternative styles, for instance Muslim punk rock and Sufi rock, which express alternative visions to Islam and Muslims.

Although the artists upholding the artistic view generally have weak ties with the field of religion, this view is not totally deprived of some appreciation for specific Islamic teachers originating from the traditional Arab or South Asian world or Europe. Swiss Egyptian Ramadan, who holds a doctorate in Arabic and Islamic Studies, receives some credits as far as revisiting ideas of contemporary faith is concerned. This public speaker has contributed, with alternative perspectives, to broadening the understanding of Islam away from the narrow sectarianism that hampered young British Muslims by addressing the contemporary, lived experience of Islam in a globalising world (Hamid 2009; Mandaville 2007, p. 319; Volpi and Turner 2007).

Perfectly fitting the conditional view, Ramadan recommends to integrate several high ethical goals in art, such as 'the preservation of the common good, welfare, diversity' and the consideration of social problems in order to gain 'balance and sincerity' within productions of art (2009). Nevertheless, disassociating himself from Muslim popular art for Muslim audiences ${ }^{45}$ Ramadan's conception may add a new notion to the cultural ideology of North American Islamic teacher Umar Faruq AbdAllah by discussing ways to create explicitly modern art, from Islamic standards, in order to conquer Western mainstream, media and culture. By mentioning different

\footnotetext{
${ }^{44}$ Livejournal (May 30, 2006). Retrieved from: punkistani.livejournal.com/37243.html (accessed August 8,2017$)$.

45 May 27, 2009, Radical Reform. A plea for Intellectual Reform Among Muslims in Europe, Soeterbeeck Programma at Aula, Radboud University Nijmegen, Nijmegen, NL.
} 
forms of art, Tariq Ramadan may be one of the few teachers aware of the significance of the Western ideal of autonomous contemporary art in order to become a fullyfledged participant in Western society.

Nevertheless, most of the performing artists concerned do not visit imams for advice that relate to artistic decisions. They find these imams trapped in strict interpretations that cannot be debated. The artists are critical of charismatic religious leaders and Muslims with what are considered curtailing practices. Muslim artists who fight to trespass dominant boundaries in art and Islam tend to have alternative authoritative sources of Islamic learning. These inspiring sources may range from using one's inner voice by instinctively considering how the Prophet would artistically decide in specific cases, to the voice of Muslim convert Michael Muhammad Knight, writer of The Taqwacores. Holding a doctorate in Islamic Studies, this novelist criticises orthodox Islam by integrating characters such as 'Sufi punk' and 'Shi' $i$ skinhead' in his novels. Using a cosmopolitan kind of spectrum, the productive artistic novelist is considered influential.

In sum, artists of the artistic view tend to have a broad scope on the concept of authority, which they find in voices expressing the value of independency. These voices know how to bridge individual with collective values on terms deriving from pluralist conceptions. Often artistically expressed in oxymoron, by positioning the acts of 'questioning' and 'revisiting' morals at the core of faith, artists of the artistic view seem to equalise the essence of art with the essence of religion. Although both the artistic and secular views are liberal kind of perspectives, this equalisation is, to a certain degree, the opposite of the secular view of those who relegate art and religion to different domains. The artistic view approaches the radical perspective with regard to Islamic authority, which challenges the very foundations of the corpus of religious knowledge. By creating productions such as Sufi Punk, Taqwacore and artistic pub-quizzes that question established knowledge in Islam, the artists embed their faith-inspired performances in local, national and Western contexts, where they negotiate their views on art and religion.

\section{Conclusion}

Empirically inspired by the longstanding discourse on the (in)compatibility of (popular) art with practised Islam and theoretically by Bourdieu's conception of the relatively autonomous field of art, this article has investigated the relationship between art, Islam and authoritative voices by way of Muslim performing artists in the UK and the US. Academic perspectives on culture, religion and Islamic authority as well as on the phenomena of the anchoring of religion in cultures and its withdrawal from cultures are taken into account in the analysis of the findings, which have revealed a considerably relevant pattern of cultural orientations among Muslims. These orientations illuminate how British and North American artists perceive and shape their social positions in the UK and the US since 2001.

Associated with preferences concerning musical styles, gender comportment and cultural differentiation, in the Anglophone field of Muslim performing artists, the five socio-cultural ideological views to the relation between art, religion and authoritative 
voices can be considered positions between which artists may shift in time depending on their professional and religious careers. The different culture vs religion views can be generally understood as matters of strategy to improve social positions. In the most central conditional view, art takes care of guidelines acquired from religion moderately. In the strict view, art anticipates on restrictions deduced from religion. In the civilisational view, culture and art are integral to religion. In the secular view, art and religion belong to different domains of life. Lastly, in the artistic view, art and religion are combined in an unconditional and reciprocal way. The civilisational view represents a new perspective with regard to academic perspectives on authoritative interpretations in the Arab world about the integration of art and faith, while the artistic view is generally underexposed in literature on Islam.

Besides noticeable differentiation, the overall field of British and North American Muslim performing artists has evolved underlying principles and purposes, which are to gain, firstly, an equal position in culture, media and society through the mode of normalising. Related is the second aim to upgrade the cultural tastes and capital of internal (disadvantaged) Muslim communities. The third goal is to create dominant Muslim leadership by means of cultural distinction to established notions and structures in the West. This goal is particularly encountered in the centre and upper part of the field, which is definitely interconnected with the field of Islam.

Although in reality more complex, the relatively strong ties between artists of the strict, conditional and civilisational views with imams and preachers are inspired by Salafi-orientations as far as the strict view is concerned, and Sufi-orientations where the civilisational view is involved. Artists of the conditional and civilisational views have salient relationships with Islamic scholars and teachers, such as from the Sufi-oriented network of 'Traditional Islam', which has been countering the huge popularity of Salafism. These authoritative voices have often given Muslim performing artists support in their distinctive expressions and sometimes advised them to restrain. Hence, in the context of particularly the civilisational view, there is little question of fragmented authority. Artists of the strict view, which is encountered predominantly among male artists in the UK, are eager to follow artistic restrictions drawn from classical and specific contemporary Islamic authoritative voices. In this sense, external moral criteria have returned to the field of art, interestingly putting Bourdieu's conception of the relative autonomy of the field of art into perspective.

Whereas the secular and artistic views are found among artists with South Asian and Middle Eastern immigrant backgrounds-born-again and born Muslims-the strict and civilisational views emerge more often among Black convert and bornagain Muslim artists, for instance of African American and Jamaican descent. Particularly the artists upholding these views have a tense relationship to culture. The strict view is often adhered to by male artists in hip-hop who have personally experienced the dangers of street and gang culture or other fatal excesses of life or know those who have. In terms of withdrawal from culture, through believing artistic restrictions may prepare them for the afterlife, they are eager to escape from the cultures surrounding them.

In contrast, identifying with the roots of Islam and its development in the West, the civilisational view achieves to upgrade the indigenous cultural tradition in the Islamic hierarchy of those whose cultural past has been wiped out, except for their 
social activist and musical heritage as embedded in the national histories, what meant the liberation of a people. Although 'cultural Islam' and its 'cultural explanations' of Islam, deriving from ethnic customs, are treated with small belittlements in the field, particularly artists with the civilisational view are critical towards the South Asian and Middle Eastern Muslim-majority kinds of discourse outside the field. Perceived to reduce the significance of the spiritual and artistic musical tradition of (indigenous) Muslim (American) culture, they oppose the exclusively pietist focus on religion and aim to anchor their (activist) cultural legacy in Islam instead. The accommodationist kind of civilisational view is therefore emancipative in the collective sense.

From different angles on mediating Islam and the contemporary world, the strict, conditional and civilisational views have reformist tendencies by expressing that some of the traditional institutions of Islamic authority ought to be revised. However, the latter view also holds that alternative indigenous institutions ought to be broadly recognised, which makes the civilisational view quite radical for claiming defining power. Almost collaborating with the American taste, for instance in the sense of being part of its global success in originally Black music, they extend and redirect the field's purposes from autonomy in the culture and media of the West to autonomy with regard to dominant Islamic notions from outside the field.

The secular and artistic orientations are much less influenced by the central moderate view in the field and its conditions to the performing arts. Whereas the civilisational view reflects several collective notions based on relatively strong ties of friendship with (Black) Islamic teachers, the secular and, especially, the artistic views comprise very individualised notions, which is common in Bourdieu's concept of the field of art. These artists with South Asian and Middle Eastern backgrounds were raised in more affluent and open-minded circumstances or, in contrast, have escaped from the perceived narrow mindsets of their former social environments. The artistic view is therefore rather emancipative with regard to the individual way. Tending to equalise the essence of art with the essence of religion, the artistic view appears to comprise the most radical perspective. Some of the encountered notions challenge the very foundations of the corpus of religious knowledge. Negotiating their view to art and Islam in oxymoron expressions, such as Sufi Punk, the artists embed their artistic faith-inspired performances in local, national Western contexts.

Compared with the UK, in the US, where religiosity is a dominant disposition, the central moderate stance has a broader presence in the field of Muslim performing artists. Due to the adherence of Blackamerican convert Muslims, this counts for the civilisational stance as well. While the Muslim concentration is higher in the UK and Islam discourse more significant, the British context displays, through the manifestation of strict as well as artistic views, the extremes of the field. American Muslim teachers and artists are regularly invited to the UK by reason of their authoritative voices.

In sum, besides the five socio-cultural views discussed above, the pattern of orientation and relative autonomy in the Anglophone field of Muslim performing artists displays two dimensions on autonomy. By seeking public recognition for cultural distinction from a dominant strand of religiosity in the overall Muslim community, the civilisational view endeavours relative social autonomy that counters the prevalent 
hierarchies and views representing the hegemony of the old Muslim world in Islam. The artistic view, resembling the established Western ideal of modern art, strives in seeking to liberate art from restrictions of artistic autonomy by positioning the acts of questioning and revisiting values and morals at the core of the faith of Islam.

Funding This study is partly funded by the Netherlands Organisation for Scientific Research NWO, and has taken place at Radboud University Nijmegen and University of Amsterdam.

Open Access This article is distributed under the terms of the Creative Commons Attribution 4.0 International License (http://creativecommons.org/licenses/by/4.0/), which permits unrestricted use, distribution, and reproduction in any medium, provided you give appropriate credit to the original author(s) and the source, provide a link to the Creative Commons license, and indicate if changes were made.

\section{References}

Abd-Allah, Umar F. 2004. Islam and the cultural imperative. A Nawawi Foundation paper. Burr Ridge: Nawawi Foundation.

Abdul-Khabeer, Suad. 2007. 'Rep that Islam': the rhyme and reason of American Islamic hip-hop. The Muslim World 97(1):125-141.

Aidi, Hisham D. 2014. Rebel music: race, empire, and the new Muslim youth culture. New York: Pantheon Books.

Anthias, Floya. 2013. Intersectional what? Social divisions, Intersectionality and levels of analysis. Ethnicities 13(1):3-19.

Baker, Raymond W. 2003. Islam without fear: Egypt and the new Islamists. Cambridge: Harvard University Press.

Becker, Howard S. 1982. Art worlds. Ewing: University of California Press.

Boubekeur, Amel. 2007. Post Islamist culture: a new form of mobilization? History of Religions 74(1):75-94.

Bourdieu, Pierre. 1966. Condition de classe et position de classe. European Journal of Sociology 7(2):201-223.

Bourdieu, Pierre. 1971. Genèse et structure du champ religieux. Revue Française de sociologie 12(3):295334.

Bourdieu, Pierre. 1996. The rules of art: genesis and structure of the literary field. Stanford: Stanford University Press. Susan Emanuel trans.

Bourdieu, Pierre. 2009. The field of cultural production: essays on art and literature. Cambridge: Polity Press. Randal Johnson (ed. and intro.).

Bourdieu, Pierre, and Lois Wacquant. 1992. An invitation to reflexive sociology. Chicago: University of Chicago Press.

Bowen, John R. 2012. A new anthropology of Islam. Cambridge: Cambridge University Press.

Brown, Frank B. 2000. Good taste, bad taste, and Christian taste: aesthetics in religious life. New York: Oxford University Press.

Bukhari, Zahid H., Sulayman S. Nyang, Mumtaz Ahmad, and John L. Esposito (eds.). 2004. Muslims' place in the American public square: hope, fears, and aspirations. New York: AltaMira Press.

Cesari, Jocelyne. 2004. When Islam and democracy meet: Muslims in Europe and in the United States. New York: Palgrave.

Curtis, I.V., and E. Edward (eds.). 2010. Encyclopedia of Muslim-American history. New York: Infobase Publishing.

De Swaan, Abraham. 1991. Kwaliteit is klasse. Perron Nederland. Amsterdam: Meulenhoff.

Esposito, John L. 1998. Islam and politics. New York: Syracuse University Press.

Geaves, Ron. 2010. Book review: Van Bruinessen, Martin \& Julia Day Howell (eds) (2007) Sufism and the 'modern' in Islam. Fieldwork in Religion 5(2):254-256.

Göle, Nilufer. 2003. The voluntary adoption of Islamic stigma symbols. Social Research 70(3):801-820.

Gombrich, Ernst H. 1982. The story of art. Oxford: Phaidon Press.

Hamid, Sadek. 2008. The development of British Salafism. ISIM Review 21(spring):10-11. 
Hamid, Sadek. 2009. The attraction of "authentic Islam": Salafism and British Muslim youth. In Global Salafism: Islam's new religious movement, ed. Roel Meijer, 352-371. Oxford: Oxford University Press.

Hamid, Sadek. 2016. Sufis, Salafis and Islamists. The contested ground of British Islamic activism. London: I.B. Tauris.

Herding, Maruta. 2013. Inventing the Muslim cool. Islamic youth culture in Western Europe. DE: Transcript Verlag.: Bielefeld.

Jackson, Sherman A. 2005. Islam and the Blackamerican. Looking toward the third resurrection. Oxford: Oxford University Press.

Jackson, Sherman A. 2009. Black orientalism: its genesis, aims, and significance for American Islam. In Black routes to Islam, ed. Manning Marable, Hishaam D. Aidi. New York: Palgrave Macmillan.

Jacobson, Janet. 1998. Islam in transition: religion and identity among British Pakistani youth. London: Routledge.

Jensen, Tina G. 2006. Religious authority and autonomy intertwined: the case of converts to Islam in Denmark. The Muslim World 96(4):643-660.

Kempers, Bram. 1992. Painting, power and patronage: the rise of the professional artist in the Italian Renaissance. London: The Penguin Press.

Khan, Muqtedar. 2003. Constructing the American Muslim community. In Religion and immigration: Christian, Jewish, and Muslim experiences in the United States. Walnut Creek: AltaMira Press.

Kubala, Patricia. 2005. The other face of the video clip: Sami Yusuf and the call for al-Fann al-Hadif. Transnational Broadcasting Studies 14(2):38-47. Retrieved from: tbsjournal.arabmediasociety.com/ Archives/Spring05/kubala.html.

Lamont, Michèle. 2000. The dignity of working men: morality and the boundaries of race, class, and immigration. New York: SAGE.

Lapidus, Ira M. 1997. Islamic Revival and Modernity: The Contemporary Movements and the Historical Paradigms. Journal of the Economic and Social History of the Orient 40(4)., 444-460.

Lapidus, Ira M. 2002. A History of Islamic Societies. Cambridge, UK: Cambridge University Press.

Mamdani, Mahmood. 2005. Good Muslim, Bad Muslim: America, the Cold War, and the Roots of Terror. NY: Random House LLC.: New York.

Mandaville, Peter. 2007. Global political Islam. New York: Routledge.

Mandaville, Peter. 2009. Hip-hop, nasheeds, and "cool" sheikhs: popular culture and Muslim youth in the United Kingdom. In In-between spaces: Christian and Muslim minorities in transition in Europe and the Middle East, ed. Christiane Timmerman, Johan Leman, Hannelore Roos, and Barbara Segaert, 149-168. Leuven: Peter Lang.

McCloud, Aminah B. 2003. Islam in America: the mosaic. In Religion and Immigration: Christian, Jewish, and Muslim experiences in the United States. Walnut Creek: Alta Mira Press.

McCloud, Aminah B. 2006. Transnational Muslims in American society. Gainesville: University Press of Florida.

Meijer, Roel. 2009. Introduction. In Global Salafism: Islam's new religious movement, ed. Roel Meijer, 1-29. New York: Oxford University Press.

Miyakawa, Felicia M. 2005. Five percenter rap: god hop's music, message, and black Muslim mission. Indianapolis: Indiana University Press.

Mohaiemen, Naeem. 2008. Fear of a Muslim planet: the Islamic roots of hip-hop. In Sound unbound: sampling digital music and culture, ed. D.J. Spooky, 303-325. Cambridge: MIT Press.

Moosavi, Leon. 2012. British Muslim converts performing "authentic Muslimness". Performing Islam 1(1):103-128.

Morey, Peter, and Amina Yaqin. 2011. Framing Muslims. Stereotyping and representation after 9/11. Cambridge: Harvard University Press.

Oosterbaan Martinius, Warna. 2005. Schoonheid, welzijn, kwaliteit. Kunstbeleid en verantwoording na 1945. Den Haag: Gary Schwartz. Retrieved from: dbnl.org/tekst/oost054scho01_01/oost054scho01_ 01.pdf.

Otterbeck, Jonas. 2004. Music as a useless activity: conservative interpretations of music in Islam. In Shoot the singer! Music censorship today, ed. Marie Korpe. London: Zed Books.

Otterbeck, Jonas. 2008. Battling over the public sphere: Islamic reactions to the music of today. Contemporary Islam 2(3):211-228.

Otterbeck, Jonas. 2016. The Sunni discourse on music. In Islam and popular culture, ed. Mark Levine, Karin van Nieuwkerk, and Martin Stokes. Austin: University of Texas Press.

Pedziwiatr, Konrad. 2011. How progressive is "Progressive Islam"? The limits of the religious individualization of the European Muslim elites. Social Compass 58(2):214-222. 
Ramadan, Tariq. 2009. Radical reform: Islamic ethics and liberation. Oxford: Oxford University Press. Rey, Terry. 2004. Marketing the goods of salvation: Bourdieu on religion. Religion 34(4):331-343.

Rose, Tricia. 2008. The hip hop wars: what we talk about when we talk about hip hop-and why it matters. New York: Basic Books.

Roy, Olivier. 2004. Globalized Islam: the search for a new Ummah. London: Colombia University Press.

Roy, Olivier. 2010. Holy ignorance: when religion and culture part ways. New York: Columbia University Press.

Shiloah, Amnon. 1995. Music in the world of Islam: a socio-cultural study. London: Scolar Press.

Sunier, Thijl. 2011. The making of Muslim youth cultures in Europe. In Mediating faiths: religion and socio-cultural change in the twenty-first century, ed. Michael Bailey, Guy Redden. Farnham: Ashgate Publishing.

Van Bruinessen, Martin, and Julia Day Howell (eds.). 2007. Sufism and the 'Modern' in Islam. London: I.B. Tauris.

Van Bruinessen, Martin, and Stefano Allievi. 2011. Producing Islamic knowledge: transmission and dissemination in Western Europe. London: Routledge.

Van de Werfhorst, Herman G., and Nan D. de Graaf. 2004. The sources of political orientations in post-industrial society: social class and education revisited. The British Journal of Sociology 55(2):211-235.

Van Tilborgh, Yolanda. 2009. Het islamdebat en de strategische emoties van moslima's. Jaarboek KennisSamenleving: Gevoel voor kennis., 98-120. Amsterdam: Uitgeverij Aksant.

Van Tilborgh, Yolanda. 2016a. From hell to heaven: the Malcolm X narrative of Muslim artists. The meaning of his life in relation to the doctrine of predestination for British and American performing artists in the 21th century. In Malcolm X: from political eschatology to religious revolutionary, ed. Dustin J. Byrd, Seyed Javad Miri, 273-320. Leiden: Brill.

Van Tilborgh, Yolanda. 2016b. Conversion strategies and the power to define: British and American Muslim performance in Bourdieu's field of art. Sociology and Anthropology 4(5):320-330.

Van Tilborgh, Yolanda. 2017. Career trajectories and (in)formalization among Muslim performing artists in the UK and the U.S. Accommodationism or fundamentalism? Journal of Religion \& Society 19(2017):1-25.

Volpi, Frédéric, and Bryan S. Turner. 2007. Introduction: making Islamic authority matter. Theory, Culture \& Society 24(2):1-19.

Wiktorowicz, Quintan. 2006. Anatomy of the Salafi movement. Studies in Conflict \& Terrorism 29(3):207239.

Yukleyen, Ahmet. 2010. Production of mystical Islam in Europe: religious authorization in the Süleymanlı Sufi community. Contemporary Islam 4(3):269-288. 